Elena Yu. Novenko ${ }^{1,2}$, Andrey N. Tsyganovi, ${ }^{2,3}$ Kirill V. Babeshko ${ }^{3}$, Richard J. Payne ${ }^{4}$, Jinlin Li ${ }^{5}$, Yuri A. Mazei ${ }^{1,3}$, Alexander V. Olchev ${ }^{1,6}$

1 Lomonosov Moscow State University, Moscow, Russia

${ }^{2}$ Institute of Geography Russian Academy of Science, Moscow, Russia

${ }^{3}$ Penza State University, Penza, Russia

${ }^{4}$ Environment and Geography, University of York, York YO105DD, United Kingdom.

${ }^{5}$ Shenzhen MSU-BIT University, Shenzhen, Guangdong province, China

${ }^{6}$ A.N. Severtsov Institute of Ecology and Evolution, Russian Academy of Sciences,

\title{
CLIMATIC MOISTURE CONDITIONS IN THE NORTH-WEST OF THE MID-RUSSIAN UPLAND DURING THE HOLOCENE
}

\begin{abstract}
This study aimed to reconstruct the climatic moisture conditions of the MidRussian Upland through the Holocene. Surface moisture conditions in the study region were inferred from published pollen records from the Klukva peatland, in the northwest of the Mid-Russian Upland. Three climatic indices were derived from previouslypublished reconstructions of mean annual temperature and precipitation: the Climate Moisture Index, the Aridity Index and the Budyko Dryness Index. A simple modeling approach to reconstruct annual potential evapotranspiration and net radiation was developed and used to estimate the indices for different periods of the Holocene. The moisture indices were compared with independent proxies of climate moisture such as peatland surface wetness, reconstructed from testate amoebae and regional fire activity, reconstructed from charcoal. Results show that the surface moisture conditions in the study region were characterized by large variability. Periods of mild temperature and moderately wet conditions were followed by dry periods, which resulted in significant changes in palaeoenvironments. The method developed for calculation of potential evapotranspiration and indices of surface moisture conditions could be a useful tool for climate reconstructions. Our results demonstrate the detailed and nuanced palaeoclimate data which can be derived from pollen data.
\end{abstract}

KEY WORDS: paleoenvironmental reconstruction, Mid-Russian Upland, climate moisture conditions, potential evapotranspiration, precipitation, Best Modern Analogue technique

CITATION: Elena Yu. Novenko, Andrey N. Tsyganov, Kirill V. Babeshko, Richard J. Payne, Jinlin Li, Yuri A. Mazei, Alexander V. Olchev (2019) Climatic moisture conditions in the north-west of the Mid-Russian Upland during the Holocene. Geography, Environment, Sustainability, Vol.12, No 4, p. 188-202

DOI-10.24057/2071-9388-2018-62 


\section{INTRODUCTION}

Information about spatial and temporal variability of climate and vegetation in past epochs is important for better understanding of climate-vegetation interactions and prediction of possible vegetation changes under future climate change scenarios. During recent decades various proxy methods have been developed and applied for reconstructions of plant species composition and regional climatic conditions (Khotinsky 1977; Zagwijn 1994; Isarin, Bohncke 1999; Krementski et al. 2000; Barber et al. 2004). Many methods are based on analysis of pollen data in order to reconstruct long-term temperature variability. While pollen-based temperature reconstructions often perform well, reconstructions of climatic moisture conditions are largely limited to assessing major changes between wetter and drier phases (Velichko et al. 2002; Stančikaite et al. 2008; Inisheva et al. 2013; Kalnina et al. 2015). Precipitation amount has been considered as key factor influencing surface moisture conditions in these studies (Khotinsky and Klimanov 1997; Nakagawa et al. 2002; Davis et al. 2003; Tarasov et al. 2009; Mauri et al. 2015). Surface evapotranspiration (potential and actual evapotranspiration) has been either ignored, or parameterized using simplified regression functions and modeling approaches (Prentice et al. 1992; Olchev and Novenko 2012; Novenko and Olchev 2015). Other studies have compared pollen-based moisture reconstructions to independent reconstructions of local surface moisture based on methods such as plant macrofossil and testate amoeba analysis from peatlands (Lamentowicz et al. 2008; Bunbury et al. 2012; Gałka et al. 2017; Tsyganov et al. 2017).

Boreal and temperate forests cover large areas of Northern Eurasia and are expected to be very sensitive to projected climate warming (Olchev et al. 2009, 2013; Novenko et al. 2014). Despite numerous studies of past temperature variability, temporal change in surface moisture conditions and effects on vegetation cover are poorly-constrained. According to the classical paradigm (the so-called 'Blytt-Sernander scheme with Khotinsky modification' (Khotinsky 1977), the climate conditions of the Holocene in the East European Plain can be classified as follows: a cold and relatively dry Boreal (10.3 - $8.8 \mathrm{ka} \mathrm{BP})$, a wet and warm Atlantic (the Holocene thermal maximum, 8.8-5.7 ka BP), a cool and dry Subboreal (5.7-2.6 ka BP) with a warm phase in its middle part, and a wetter Subatlantic (2.6 ka BP - present). Recent studies have however demonstrated that the Holocene climate conditions in the East European Plain were characterised by greater variability than was previously supposed. Specifically, it has been shown that the Boreal period included a humid phase between 9.3 and 9.1 ka BP (Fleitmann et al. 2008; Novenko and Olchev 2015). The early Atlantic warming period was interrupted by a short-term but abrupt cooling, the so-called ' 8.2 ka event', which has been traced, almost simultaneously, in northwestern Europe (Alley et al. 1997; Allen et al. 2007; Thomson et al. 2007). The late Atlantic (7.0-5.5 ka BP) may have been relatively dry in Eastern Europe as studies have shown decreased river discharge in Central European Russia (e.g. Sidorchuk et al. 2012) and very high fire frequency in some regions of the East European Plain (Novenko et al. 2016, 2017).

In this study we attempt to develop a detailed reconstruction of Holocene climate moisture conditions in the north-west of the Mid-Russian Upland. The study area is situated close to the southern boundary of the mixed coniferous-broad leaved forest zone, in the ecotone between forest and steppe zones (Fig. 1). This combination makes the vegetation of the area very sensitive to changes in regional thermal and moisture conditions. To reconstruct moisture conditions through the Holocene we use several different surface moisture indices: the Aridity Index, the Budyko Dryness Index and the Climate Moisture Index. All of these indices classify moisture conditions as the difference between available annual precipitation and potential land surface evapotranspiration. For the reconstruction of these parameters we use previously-published pollen-based reconstructions of the mean annual temperature and precipitation from a small peat 
bog (Klukva) situated in the northwestern part of the Mid-Russian Upland (Novenko et al. 2015). To verify reconstructed moisture conditions of the study area through the Holocene we compare pollen-based reconstructions to independent proxy data on peatland surface wetness inferred from testate amoebae (Tsyganov et al. 2017) and to reconstructed regional fire activity, based on charcoal (Novenko et al. 2018).

\section{MATERIALS AND METHODS}

\section{Study area}

The Klukva peatbog $\left(53.834^{\circ} \mathrm{N}, 36.252^{\circ} \mathrm{E}\right)$ is located on the sandy fluvio-glacial plain adjacent to the right bank of the Upper Oka River, near the town of Belyov (Tula region) in the north-western part of the Mid-Russian Upland (Fig. 1). Early-to-Middle Pleistocene fluvio-glacial sands are underlain by Lower Carboniferous limestones, resulting in active karst processes. Previous studies by Novenko et al. (2015) have shown that the Klukva peatbog was formed in a sink hole (280 cm depth) around $10.0 \mathrm{ka}$ BP. An age-depth model of the peat core has been developed based on 6 radiocarbon dates using the "clam 2.2" package (classical agedepth modelling; Blaauw 2010).

The climate of the study area is temperate and moderately continental with a mean annual air temperature $+5.5^{\circ} \mathrm{C}$ and mean January and July temperatures of $-9.7^{\circ} \mathrm{C}$ and $+19^{\circ} \mathrm{C}$, respectively. The mean annual precipitation is about $600 \mathrm{~mm}$ [http://www. meteo.ru]. The vegetation cover of Klukva peatbog largely consists of ombrotrophic species with Pinus sylvestris, Oxycoccus palustris, Eriophorum vaginatum and Sphagnum mosses particularly abundant (Volkova 2011). The peatbog is surrounded by very diverse mesophytic and hygromesophytic coniferous and mixed broadleaf-coniferous forests (Bohn et al. 2003). The main forest forming species in the area are Picea abies, Tilia cordata, Quercus robur, UImus laevis, UImus glabra and Acer platanoides. Scots Pine (Pinus sylvestris) forests are also present in areas of sandy soils (Fig. 1).

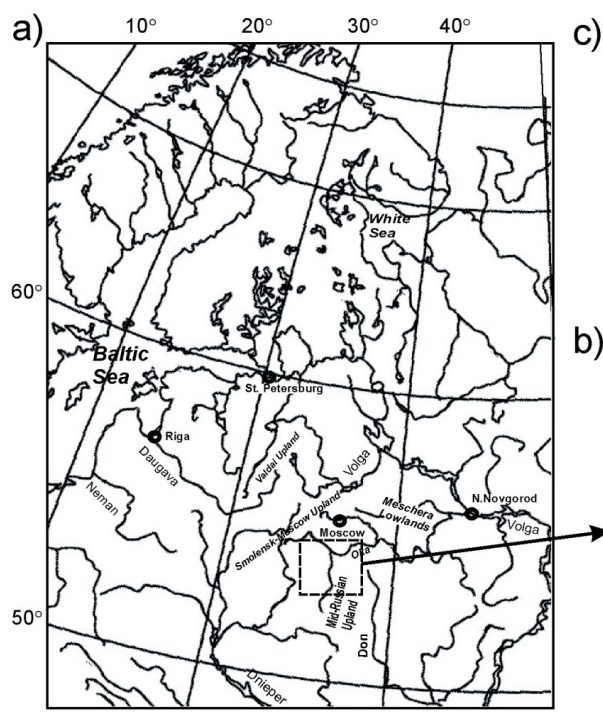

c)

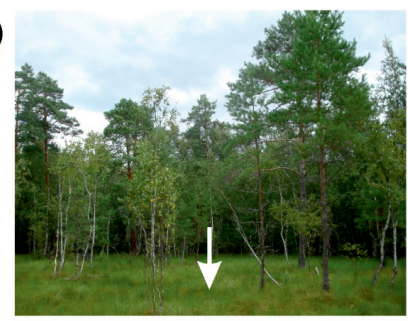

b)

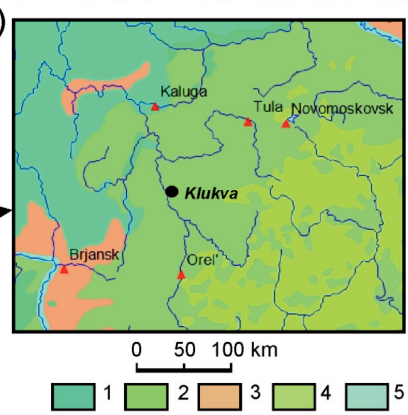

Fig. 1. Location of the study area

a) Location of the Mid-Russian Upland within the East European Plain

b) Vegetation map of the Mid-Russian Upland (after Bohn et al., 2003) and location of the Klukva peatland. Vegetation units: 1 - Mesophytic and hygromesophytic coniferous and mixed broadleaf-coniferous forests; 2 - Mesophytic deciduous broadleaf and mixed coniferous-broadleaf forests; 3 - Boreal and hemiboreal pine forests, 4 - Forest steppe; 5 - Vegetation of flood-plains and other moist or wet sites. c) Klukva peatland and location of the coring site 


\section{Reconstruction of the air temperature and precipitation}

Mean annual temperature and precipitation were reconstructed using the Best Modern Analogue (BMA) technique, based on pollen data. Details of the BMA approach have been described in many previous publications (e.g. Nakagawa et al. 2002; Williams and Shuman 2008) and the implementation applied here has been described and tested in several studies in various regions of the East European Plain (Novenko et al. 2015; 2016; 2017). The main principles of this technique can be summarized as follows: (i) comparing the fossil pollen assemblages with modern pollen assemblages using squared-chord distance (SCD) as the index of dissimilarity between pollen spectra (two spectra are considered analogous if their SCDs are less than a threshold "T" value); (ii) for each fossil assemblage selecting the closest modern pollen assemblages (the best modern analogues). The climatic characteristics (temperature, precipitation, etc.) of these selected best analogues are then averaged to estimate the environmental conditions represented by the fossil assemblage. The threshold value used in our study is 0.1 . We kept eight best modern analogues for data analysis as recommended by Nakagawa et al. (2002). BMA calculations were undertaken using Polygon 1.5 software (http://polsystems.rits-palaeo.com).

As modern analogues for our reconstruction we used 720 pollen spectra originating from a wide diversity of landscapes in Northern Eurasia, including European Russia and Siberia (Novenko et al. 2014). All modern surface samples were extracted from the European Pollen Database (Davis et al. 2014). Climatic information was taken from the BRIDGE Earth System Modelling dataset (https://www.paleo.bristol.ac.uk).

Analogue selection was geographically constrained (Williams and Shuman 2008). We used surface pollen spectra only from the places in which the modern vegetation and environmental conditions could be considered potentially analogous for Holocene paleoenvironments in the forest zone of the East European Plain. Therefore we re- stricted the area of calibration datasets to the northern and eastern parts of Europe, and Western Siberia $\left(30-55^{\circ} \mathrm{N}, 45-65^{\circ} \mathrm{E}\right)$.

To test the accuracy of climate reconstructions based on the BMA approach, a leaveone-out cross-validation was applied to the modern training set (Ter Braak 1995). One modern pollen spectrum was sequentially removed from the total modern data set and mean annual temperature and precipitation were calculated for our site on the basis of the remaining data.

Comparisons of pollen-based reconstructions of mean annual temperature with observed values in the sites show a strong correlation $\left(R^{2}=0.81\right.$, RMSEP $\left.=1.5^{\circ} \mathrm{C}\right)$. Correlation between reconstructed and observed values of annual precipitation are somewhat lower $\left(R^{2}=0.51\right.$ and RMSEP $=$ $101 \mathrm{~mm}$ ); however we assume that they are nevertheless adequate for the reconstruction of prevailing climatic changes in the area.

It is clear that climatic reconstructions provided by the BMA approach are reliable only in the case of undisturbed vegetation not affected by human activity. In our pollen records from the Klukva peatbog, three periods of human impact were identified: the Neolithic occupation (5.2 - 4.3 ka BP), the Middle Ages (about 1.2-0.9 ka BP) and the last 300 years (Novenko et al. 2015). These periods with pollen assemblages representing vegetation disturbance were therefore excluded from our data analysis.

\section{Indices of surface moisture conditions}

To quantify change in surface moisture conditions through the Holocene we re-analysed the results of published paleoreconstructions of annual temperature and precipitation. From the pollen-based reconstructions we calculated three indices characterizing surface moisture conditions: the Aridity Index, the Budyko Dryness Index and the Climate Moisture Index (Fig. 2).

The Aridity Index (Al) is calculated as (UNEP 1992):

$A I=P / P E T$ 
where PET is the annual potential evapotranspiration ( $\mathrm{mm} / \mathrm{yr})$, and $P$ is the annual precipitation $(\mathrm{mm} / \mathrm{yr})$. For humid and sub-humid areas $\mathrm{Al}$ is typically greater than 0.65, while for dry sub-humid areas $A l$ is typically between 0.50 and 0.65 and for semi-arid and arid areas $A$ l is typically lower than 0.50 (UNEP 1992).

๙2 The Budyko Dryness Index (DI) can be calculated as (Budyko 1958):

$$
D I=R n / \lambda P
$$

where $R n$ is mean annual net radiation at ground surface (MJ m $\mathrm{m}^{-2} \mathrm{r}^{-1}$ ) and $\lambda$ is latent heat of vaporization $\left(\mathrm{MJ} \mathrm{kg}^{-1}\right)$. The ratio of $R n$ and $\lambda$ can be considered as a rough equivalent to potential evapotranspiration rate. The $R n$ value in our study is calculated as a sum of mean daily net radiations estimated taking into account the annual variability of incoming solar radiation, surface albedo, air temperature, etc. For excessively wet areas $D /$ is typically lower than 0.45 , for wet areas it ranges between 0.45 and 1.0, for insufficiently wet areas D/ varies between 1.0 and 3.0 and dry areas are characterized by $D />$ 3.0 (Giese 1969).

An Annual Average Climate Moisture Index (CMI) has been suggested by Willmott and Feddema (1992) and compared to other dryness and moisture indexes it is well adapted to evaluating moisture conditions in both dry and humid regions. The CMI indicator ranges from -1 to +1 and can be computed as:

$$
C M I=\left\{\begin{array}{l}
(P / P E T)-1 \text { when } P<P E T \\
1-(P E T / P) \text { when } P \geq P E T
\end{array}\right.
$$

Wet climates are characterized by positive $C M I$, and dry climates by negative CMI, respectively. To quantify the various surface moisture conditions we used the nine categories described in Table 1.

These categories were determined according to the drought index classification suggested by Rind and Lebedeff (1984). Annual $P$ is obtained by the BMA technique and annual PET is assumed to be equal to potential evaporation $(P E)$, is simulated based on the well-known Priestley-Taylor equation (Priestley, Taylor 1972) from mean daily PE values $\left(P E_{d}\right)$ as:

$P E T=P E=\int_{1}^{N_{d}} P E_{d} \cdot d t=\alpha_{P T} \cdot \int_{1}^{N_{d}}\left(\frac{\Delta}{\Delta+\gamma} \cdot \frac{R n_{d}}{\lambda}\right) \cdot d t$

where $N_{d}$ is the number of the days per year, $\gamma$ is the psychrometric constant $(\gamma=0.0665$ $\left.\mathrm{kPa}{ }^{\circ} \mathrm{C}^{-1}\right), a_{P T}$ is the Priestley-Taylor constant $\left(a_{P T}=1.26 \mathrm{~mm}\right.$ day $\left.^{-1}\right)$ and $\Delta$ is the slope of the relationship between saturation vapor pressure and the air temperature $\left(\triangle, \mathrm{kPa}^{\circ} \mathrm{C}^{-1}\right)$.

$\triangle$ can be parameterized as:

\section{Table 1.The main categories applied to describe the surface moisture conditions using} the Climate Moisture Index

\begin{tabular}{|c|c|}
\hline CMI ranges & Categories of surface moisture conditions \\
\hline 0.8 to 1.0 & Extremely wet \\
\hline 0.6 to 0.8 & Severely wet \\
\hline 0.2 to 0.6 & Moderately wet \\
\hline 0 to 0.2 & Mildly wet \\
\hline 0.0 & Normal \\
\hline-0.2 to -0.0 & Mildly dry \\
\hline-0.6 to -0.2 & Moderately dry \\
\hline-0.8 to -0.6 & Severely dry \\
\hline-1.0 to -0.8 & Extremely dry \\
\hline
\end{tabular}




$$
\Delta=\frac{4098.0 \cdot\left[0.6108 \cdot \exp \left(\frac{17.27 \cdot T}{T+237.3}\right)\right]}{(T+237.3)^{2}}
$$

where $T$ is the mean daily air temperature on the sequential day of the year. This is approximated by a sine function using reconstructed mean annual temperature and annual temperature range.

The daily net radiation at ground surface is derived as a sum of short-wave $\left(R n_{s}\right)$ and long-wave $\left(R n_{1}\right)$ radiation balances:

$$
R n=R n_{s}+R n_{l}=Q \cdot(1-\alpha)+\left(R_{i l}-R_{o l}\right)
$$

where $Q$ is the incoming daily solar radiation, $a$ is the surface albedo and $R_{i l}$ and $R_{o l}$ are the incoming and outgoing long-wave radiation, respectively. Surface albedo depends on vegetation types (e.g. coniferous forest, deciduous forest, mixed forest, grassland), soil properties and forest cover percentage.

Following to McMahon et al (2013) the equation for $Q$ can be written as:

$Q=Q_{S} \cdot(0.85-0.047 \cdot N)$

where $N$ is the number of tenths of the sky covered by clouds and $Q_{S}$ is mean daily solar radiation on a horizontal surface at the top of the Earth's atmosphere, which can be calculated as:

$$
\begin{aligned}
Q_{S}= & 86400 / \pi \cdot Q_{S 0} \cdot d_{r}^{2} \cdot\left(\omega_{S} \cdot \sin \varphi \cdot \sin \delta+\right. \\
& \left.+\cos \varphi \cdot \cos \delta \cdot \sin \omega_{S}\right)
\end{aligned}
$$

where $Q_{S 0}$ is the solar constant $\left(Q_{s 0}=0.001367 \mathrm{MJ} \mathrm{m}^{-2} \mathrm{~s}^{-1}\right), \varphi$ is latitude, $d_{r}$ is the inverse relative distance between the Earth and the Sun, $\delta$ is the solar declination angle, and $\omega_{s}$ is the sunset hour angle.

Equations for $\mathrm{d}^{\prime}$ can be written as (McMahon et al. 2013):

$$
d_{r}=1+0.033 \cdot \cos (2 \pi \cdot d o y / 365) \text {, }
$$

for $\omega_{s}$ as:

$$
\omega_{S}=\arccos (-\tan \varphi \cdot \tan \delta)
$$

and for $\delta$ as:

$$
\delta=0.409 \cdot \sin (2 \pi \cdot d o y / 365-1.39)
$$

where doy is the sequential day number of the year.
The equations for $R_{i l}$ and $R_{o l}$ are written as:

$$
\begin{aligned}
R_{o l}= & 0.97 \cdot \sigma \cdot(T+273.16)^{4} \\
R_{i l}= & \left(C_{f}+\left(1-C_{f}\right) \cdot(1-(0.261 \cdot \exp (-7.77 \times\right. \\
& \left.\left.\left.\left.\times 10^{-4} \cdot T^{2}\right)\right)\right)\right) \cdot \sigma \cdot(T+273.16)^{4}
\end{aligned}
$$

where $\sigma$ is the Stefan-Bolzmann constant $\left(\sigma=4.903 \times 10^{-9} \mathrm{MJ} \mathrm{m}^{-2} \mathrm{~K}^{-4}\right.$ day $\left.^{-1}\right)$ and $C_{f}$ the fraction of cloud cover that is derived empirically as a function of mean daily precipitation (McMahon et al. 2013).

\section{Reconstruction of peatland surface wet- ness}

Peatland surface wetness in terms of the water table depth (WTD, cm), has been suggested to be a useful proxy for climate moisture conditions. WTD was reconstructed from palaeoecological data (Novenko et al. 2015) using a testate amoeba-based transfer function (inverse weighted averaging regression model) which was specifically developed for the forest zone of European Russia (Tsyganov et al. 2017). The transfer function included 80 samples from 18 peatlands located in the taiga, mixed and broadleaf forest, and forest-steppe zones of European Russia. Leave-one-out cross-validation showed reasonably strong model performance $\left(R^{2}\right.$ $=0.74$; RMSEP $=5.5 \mathrm{~cm}$ ). In ombrotrophic peatlands, water-table depths inferred from testate amoebae generally reflect the length and severity of the summer moisture deficit, which may correspond to rate of summer precipitation and evapotranspiration (Charman 2007).

\section{Reconstruction of fire activity}

As an additional independent proxy for climate moisture conditions we used the macro-charcoal record from the Mochulya peatland in the "Kaluzhskie Zaseki" Natural Reserve, located $70 \mathrm{~km}$ to the north-west of the Klukva peatbog. The results of macro-charcoal analysis were expressed as charcoal concentration (pieces $\mathrm{cm}^{-3}$ ). The chrononology for the cores is based on 5 radiocarbon dates with an age-depth model produced by the "clam 2.2" package (Blaauw, 2010). The main source of macroscopic charcoal particles (>125 $\mu \mathrm{m})$ 


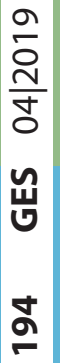

\section{CMI}
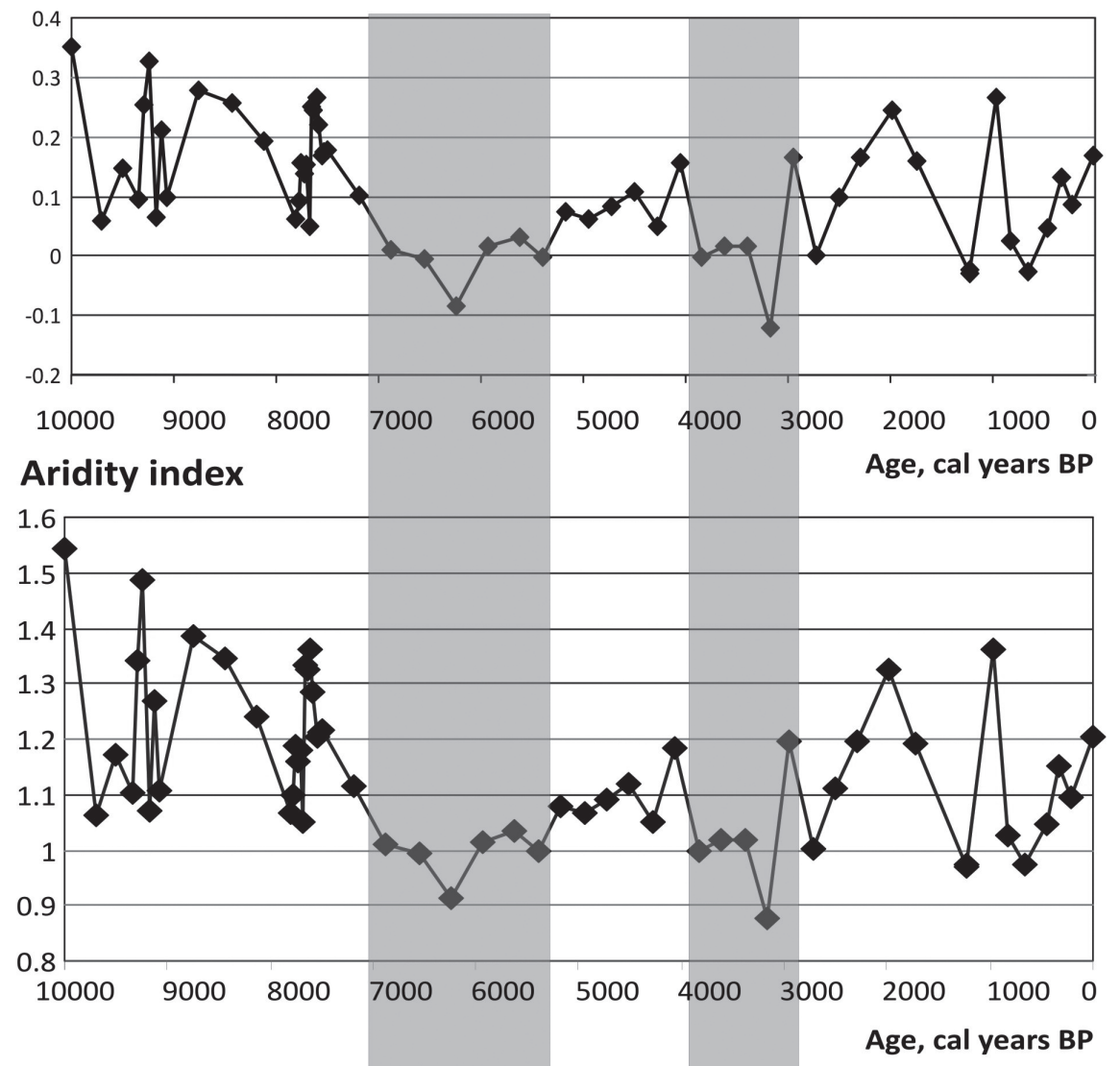

\section{Dryness index of Budyko}

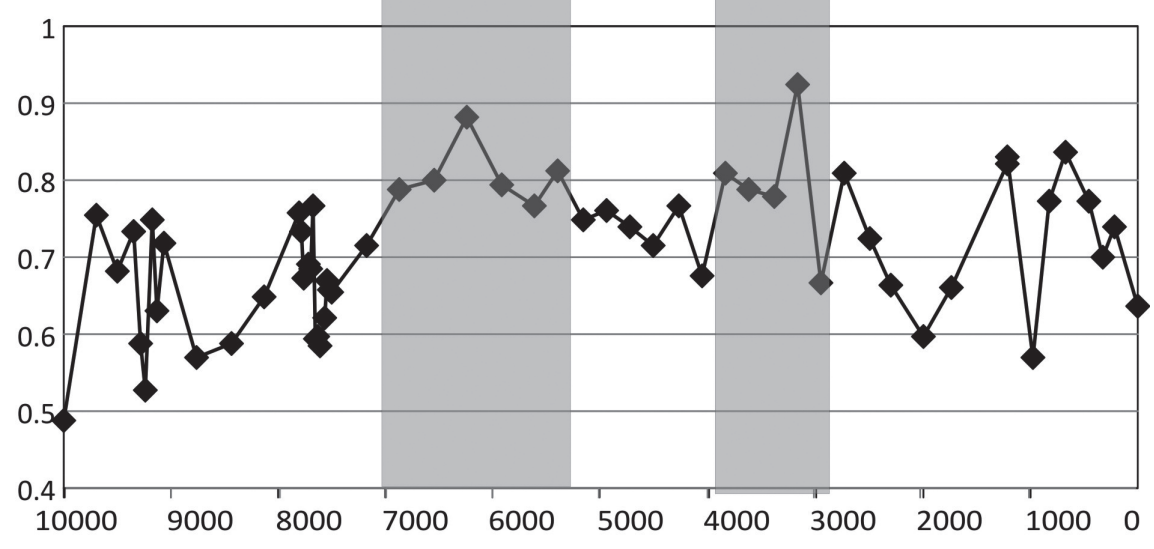

Age, cal years BP

Dry phases

Fig. 2. Indices of surface moisture conditions: Climate Moisture Index, Aridity Index and Budyko Dryness Index. Grey bands indicate dry periods 
in peat deposits is assumed to be atmospheric deposition as a result of convective processes arising from the thermal effects of fires (Mooney and Tinner 2011). Fire occurrence and intensity can be assumed to represent climatic aridity in the absence of human activity. Macro-charcoal records are available for the last 4200 cal years only.

\section{RESULTS AND DISCUSSION}

We reconstructed variability in environmental conditions over the last $10.0 \mathrm{ka} \mathrm{BP}$ (Fig. 2) using pollen-based modeling approaches for the reconstruction of changes in surface moisture indices, and compared them with independent proxy data (Fig. 3). Pollen data showed that the study area was occupied mainly by pine-birch forests with minor admixture of Quercus, Tilia and Ulmus between 10.0 and 8.5 ka BP (the second part of the Boreal period). During this period the climate was colder than today with the mean annual temperature around $3-4^{\circ} \mathrm{C}, 2-3^{\circ} \mathrm{C}$ lower than at present. The annual precipitation was close to modern val- ues (about $600 \mathrm{~mm}$ per year). Overall, the climate in the period was relatively humid: CMI reached 0.3-0.4 (moderately wet); the Aridity Index was around 1.5 and the Budyko Dryness Index varied from 0.5 to 0.8 (Fig. 2). WTD reconstructed from testate amoeba data was not lower than $5 \mathrm{~cm}$, indicating a relatively high water table and a wet peatland surface environment.

During the period 10.0-8.5 ka BP, climatic fluctuations with a duration of several centuries were identified. A cooling phase detected at 9.3-9.2 ka BP correlates with the 9.2 ka event (Fleitmann et al. 2008). This cooling was associated with increased precipitation (by about $100 \mathrm{~mm}$ ), and reduced potential evapotranspiration. As result, the CMI in the period declines to 0.1 , corresponding to moderately wet surface moisture conditions (Fig. 3).

Between 8.5 and 6.7 ka BP climate was warm and moderately wet. The mean annual temperatures reached $6-7.5^{\circ} \mathrm{C}, 1.0-2.5^{\circ} \mathrm{C}$ higher than at present. The mean annual precip-

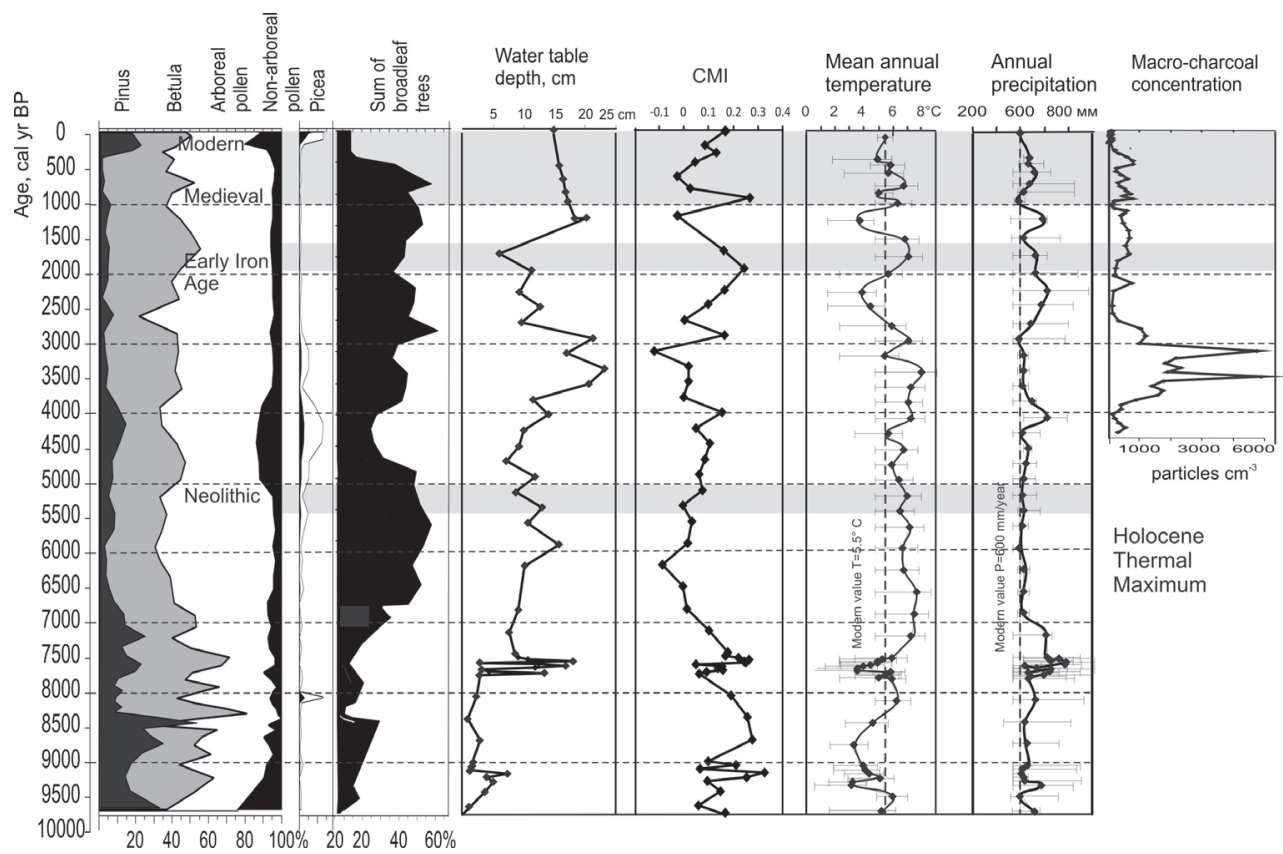

Fig. 3. Summary of pollen records from the Klukva peatland, reconstruction of climatic conditions and water table depth inferred from pollen and testate amoeba data; macro-charcoal data from the Mochulya peatland, located in the Kaluzhskie Zaseki Natural Reserve. Grey bands indicate periods of probable vegetation disturbance due to human impact 
itation increased to $800 \mathrm{~mm}$ and exceeded modern values by $200 \mathrm{~mm}$. CMI increased up to 0.3 (around $7.5 \mathrm{ka} \mathrm{BP}$ ); the Aridity Index decreased to 1.3-1.4 and the Budyko Dryness Index was close to 0.6 (Fig. 2) Reconstructed WTDs varied from 5 to $10 \mathrm{~cm}$, indicating a moderately wet peatland surface environment (Fig. 3). Vegetation cover was represented by Quercus forests with an admixture of Ulmus, Tilia, Fraxinus and Corylus in the understory (Novenko et al. 2015). This species composition persisted in the study area during the middle and late Holocene, until disturbance by humans in historical time.

In the period 6.7-5.5 ka BP, the mean annual precipitation decreased to modern values while the temperatures remained somewhat higher than at present. Climate conditions became somewhat drier than present, as demonstrated by surface moisture indices (Fig. 2): CMI decreased to -0.1 (mildly dry) and the Aridity Index dropped to 0.9-1.0 while the Budyko Dryness Index increased to 0.8-0.9. Reconstructed WTDs fell to $15 \mathrm{~cm}$, probably due to reduced summer precipitation and/ or greater evapotranspiration. These findings agree well with evidence for decreased river discharge in the Don and Dnieper Rivers basins during this time (Sidorchuk et al. 2012), and evidence for very high frequencies of forest fires in the Meschera Lowlands (Novenko et al. 2016; Dyakonov et al. 2017).

During the next phase, 5.5-3.7 ka BP, mean annual temperatures decreased to modern values, and mean annual precipitation varied around $600 \mathrm{~mm}$. CMl rose up to 0.2 , indicating increased climate humidity. The Aridity Index varied from 1.1 to 1.2 and the Budyko Dryness Index was 0.7-0.8 (Fig. 2). WTD increased to $10-12 \mathrm{~cm}$, suggesting slightly wetter surface conditions as compared to the previous period. This climate deterioration and increased surface wetness coincided with global climate cooling (Davis et al. 2003; Mauri et al. 2015) and glacier advances in the Northern Hemisphere (Solomina et al. 2015) after 5.7 ka BP. General circulation model simulations show a clear tendency for climate cooling in Northern and Central Europe during the period, primarily driven by decreased air temperatures in the summer (Wanner et al. 2008).
A warm and extremely dry phase was detected between 3.7 and 2.7 ka BP. Mean annual temperatures increased to $7-8^{\circ} \mathrm{C}, 1.5-2.5^{\circ} \mathrm{C}$ higher than at present, while precipitation was similar to modern values. An increase in surface dryness was also shown in the dynamics of the moisture indices considered here. The CMI was about - 0.1 (mildly dry) and reached its minimum for the entire period under consideration; the Aridity Index decreased to 0.9-1.0 and the Budyko Dryness Index was 0.8-0.9. WTD in the peatland fell to a depth of $20-25 \mathrm{~cm}$, the maximum water table depth in the Klukva mire for the entire Holocene indicative of very dry conditions.

Indirect evidence for dry climate conditions during this period is provided by a large amount of macro-charcoal in the Mochulya peatland in the "Kaluzhskie Zaseki" Natural Reserve (Novenko et al. 2018). It is well known that the frequency and severity of forest fires depends on various factors such as climate conditions, vegetation type, soil water availability and human impact (Whitlock et al. 2010; Dyakonov et al. 2017). In the areas where human activity was relatively low, fire events occur more frequently during dry climatic periods, while fire frequency typically declines with increasing climatic moisture (Clear et al. 2014). In the time interval 3.7-2.7 ka BP macro-charcoal accumulation rates in peat cores from the Mochulua peatland were an order of magnitude higher than in subsequent periods (Fig. 3). In the absence of any human impact, the high fire activity is likely to have been caused by summer drought.

Climatic reconstructions in the south taiga vegetation zone have also shown warm and dry phases during the same time interval (Novenko et al. 2017). Based on pollen and testate amoeba data taken from the Staroselsky Moch peatbog, in the south of Valdai Hills the mean annual temperature exceeded modern-day values by $1-2^{\circ} \mathrm{C}$ between 3.4 and $2.5 \mathrm{ka} \mathrm{BP}$, while the $\mathrm{CMI}$ decreased to its minimum values. The WTD in the Staroselsky Moch peatbog dropped to $20-25 \mathrm{~cm}$ during this time period and reached the deepest level for the entire Holocene (Payne et al. 2016). 
During the period 2.7-2.0 ka BP, climate in the study area became cooler and wetter. The mean annual temperature dropped to $4^{\circ} \mathrm{C}$ and the mean annual precipitation reached $700 \mathrm{~mm}$ (Fig. 3). The CMI increased to 0.1-0.2 (mildly wet), the Aridity Index ranged between 1.0 and 1.1 and the Budyko Dryness Index decreased to 0.7-0.6 (Fig. 2). In this period, WTD was $7-12 \mathrm{~cm}$, which is typical for relatively humid climate conditions. This cooling was superimposed on the global temperature decline in Europe, mainly due to summer cooling from 2.7-2.6 ka BP (Wanner et al. 2011; Mauri et al. 2014). An increase in climate moisture in Eastern Europe after 2.6 ka BP was accompanied by increased rates of peat accumulation in ombrotrophic peatbogs in the forest zone of the East European Plain (Klimanov, Sirin 1997; Inisheva et al. 2013; Kalnina et al. 2013; Novenko et al. 2017), by decreased water table depth in the peatlands of Poland (Gałka et al. 2017) and reduced fire frequencies in different regions of European Russia and Eastern Europe (Clear et al. 2014; Novenko et al. 2016, 2017; Dyakonov et al. 2017).

The next warm phase in the study area was identified between 2.0 and $1.7 \mathrm{ka}$ BP. The mean annual temperatures rose to $7^{\circ} \mathrm{C}$ and precipitation varied from 600 to $700 \mathrm{~mm}$ per year (Fig. 3) implying relatively wet climatic conditions. The CMI in the period exceeded 0.2 (moderately wet), the Aridity Index was 1.3 and the Budyko Dryness Index was 0.6 (Fig. 2). WTD moved to $5-10 \mathrm{~cm}$, indicating high surface wetness in the peatbog. This phase with relatively warm climate could correlate with the Roman Warm Period ( 200 BC-600 AD/ 2.2 - 1.4 ka BP; Davis et al. 2003). This warming was followed by cooling between 1.4 and $1.0 \mathrm{ka}$ BP with the mean annual temperature declining to $4^{\circ} \mathrm{C}$ and precipitation around $700 \mathrm{~mm}$ per year. Probably, this period corresponded to the European cooling of the 'Dark Ages' (Helama et al. 2017). However, this cooling was represented in the peat core from the Klukva mire by a single sample that is not sufficient for any accurate conclusions. Climate dynamics during the last millennium were characterized by a series of short-term warm and cool intervals (Mauri et al. 2015). Surface moisture conditions varied between moderately wet and mildly dry (Fig. 2). Low sampling resolution due to low peat accumulation rate or, probably, loss of part of the peat profile due to a fire, and the probability for human impacts on the vegetation, did not allow us to make reliable climatic reconstructions for the last 1000 years.

\section{CONCLUSIONS}

The results of climatic reconstructions based on pollen data from the Klukva peatbog show clear temporal variability in surface moisture conditions, derived by the modelling approaches applied here. This study shows that in the study area during the Holocene, the CMI index reached -0.13 in the period 3.7-2.7 ka BP and -0.09 in the period 6.7-5.5 ka BP which corresponded to mildly dry conditions, to $0.30-0.35$ in the period between 10.0 and $8.5 \mathrm{ka} \mathrm{BP}$, indicating a moderately wet climate. The Aridity Index ranged between 0.88 and 1.6 (humid and sub-humid climate) through the Holocene, and the Budyko Dryness Index from 0.49 to 0.93 (wet climate). The temporal variability of surface moisture conditions agreed well with indirect estimation of climate wetness using testate amoeba data and macro-charcoal analysis.

Our research is the first reconstruction of the moisture characteristics for the Central European Russia. It is clear that fully representative reconstructions of the climatic conditions in the study region require additional data showing, in particular, the spatial variability of temperature and moisture conditions along meridional and zonal profiles crossing the Mid-Russian Upland from the south to the north and the west to the east. This study provides new data and methodological insights towards this aim.

\section{ACKNOWLEDGEMENTS}

Climatic reconstructions and pollen analysis contribute to the Russian Academy of Sciences Fundamental Research Program, State Task 0127-2019-0008, Registration Number 119021990092-1. Testate amoebae analysis was supported by RFBR project 17-04-00320. 


\section{REFERENCES}

Allen J.R.M., Long A.J., Chris J. Ottle C.J., Pearson D.G. and Huntley B. (2007). Holocene climate variability in northernmost Europe. Quaternary Science Reviews, 26, pp. 14321453.

Alley R.B. and Ágústsdóttir M.A. (2005). The 8k event: cause and consequences of a major Holocene. Quaternary Science Reviews 24, pp. 1123-1149.

Barber K., Zolitschka B., Tarasov P. and Lotter A.F. (2004). Atlantic to Urals - the Holocene climatic record of mid-latitude Europe. In: R.W. Battarbee et al. eds. Past Climate Variability through Europe and Africa. Dordrecht, Kluwer Academic Publishers, pp. 417-442.

Blaauw M. (2010). Methods and code for 'classical' age-modelling of radiocarbon sequences. Quaternary Geochronology, 5, pp. 512-518.

Bohn U., Neuhäusl R., Gollub G., Hettwer C., Neuhäuslová Z., Schlüter H. and Weber H. (2003). Map of the Natural Vegetation of Europe. Münster: Landwirtschaftsverlag.

Budyko M.I. (1958) The Heat Balance of the Earth's Surface, US Department of Commerce, Washington, D.D., 259 p.

Bunbury J., Sarah A., Finkelstein S. A. and Bollmann J. (2012). Holocene hydro-climatic change and effects on carbon accumulation inferred from a peat bog in the Attawapiskat River watershed, Hudson Bay Lowlands, Canada, Quaternary Research, 78, pp. 275-284.

Charman D.J. (2007). Summer water deficit variability controls on peatland water-table changes: implications for Holocene palaeoclimate reconstructions. The Holocene, 17 (2), pp. 217-227.

Clear J.L., Molinari C. and Bradshaw R.H.W. (2014). Holocene fire in Fennoscandia and Denmark. International Journal of Wildland Fire, 23 (6)., pp.781-789.

Davis B.A.S, Zanon M., Collins P., Mauri A. et al. (2014). The European modern pollen database (EMPD). Project. Vegetation History and Archaeobotany, 22 (6)., pp. 521-530.

Dyakonov K., Novenko E., Mironenko I., Kuprijanov D. and Bobrovsky M. (2017). The Role of Fires in the Holocene Landscape Dynamics of the Southeastern Part of Meshchera Lowlands. Doklady Earth Sciences, 477 (1), pp. 1336-1342.

Isarin R.F.B. and Bohncke S.J.P. (1999). Mean July Temperatures during the Younger Dryas in Northwestern and Central Europe as Inferred from Climate Indicator Plant Species. Quaternary Research, 51, pp. 158-173.

Fleitmann D., Mudelsee M., Burns S.J., Bradley R.S., Kramers J. and Matter A. Evidence for a widespread climatic anomaly at around 9.2 ka before present (2008). Paleoceanography and Paleoclimatology [online] Volume 23 (1), Available at: https://agupubs.onlinelibrary. wiley.com/doi/abs/10.1029/2007PA001519. [Accessed 2 Oct. 2018].

Gałka M., Tobolski K., Lamentowicz Ł., Ersek V., Jassey, V.E.J., van der Knaap W.O. and Lamentowicz M. (2017). Unveiling exceptional Baltic bog ecohydrology, autogenic succession and climate change during the last 2000 years in CE Europe using replicate cores, multi-proxy data and functional traits of testate amoebae. Quaternary Science Reviews, 156, pp. 90-106. 
Giese E. (1969). Die Klimaklassifikation von Budyko und Grigor'ev. Erdkunde, XXIII(4): pp. 317-325.

Hansen M., Townshend J., De Fries R. and Carroll M. (2005). Estimation of tree cover using MODIS data at global, continental and regional/local scales. International Journal of Remote Sensing, 26(19), pp. 4359-4380.

Inisheva L.I., Kobak K.I. and Turchinovich I.E. (2013). The development process of waterlogging and rate of accumulation of carbon in wetland ecosystems Russia. Geography and Natural Resources, 3, pp. 60-68 (in Russian).

Kalnina L., Stivrins N., Kuske E., Ozola I., Pujate A., Zeimule S., Grudzinska I. and Ratniece V. (2015). Peat stratigraphy and changes in peat formation during the Holocene in Latvia. Quaternary International, 383, pp. 186-195.

Khotinski N.A. (1977). Holocene of the Northern Eurasia. Moscow: Nauka (in Russian).

Khotinski N.A. and Klimanov V.A. (1997). Alleröd, Younger Dryas and early Holocene PalaeoEnvironmental Stratigraphy. Quaternary International, 41/42, pp. 67-70.

Klimanov V.A. and Sirin A.A. (1997). Dynamics of peat accumulation in peatbogs of the Northern Eurasia during the last 3000 years. Doklady Earth Science, 354 (5), pp. 683-686.

Krementski K.V., Borisova O.K., Zelikson E.M. (2000). The Late Glacial and Holocene history of vegetation in the Moscow region. Paleontological Journal, 34 (1), pp. 67-74.

Lamentowicz M., Cedro A., Gałka M., Miotk-Szpiganowicz G., Mitchell E.A.D., Pawlyta J. and Goslar T. (2008). Last millennium palaeoenvironmental changes from a Baltic bog (Poland), inferred from stable isotopes, pollen, plant macrofossils and testate amoeba. Palaeogeography, Palaeoclimatology, Palaeoecology, 265, pp. 93-106.

McMahon T.A., Peel M.C., Lowe L., Srikanthan R., McVicar T.R. (2013). Estimating actual, potential, reference crop and pan evaporation using standard meteorological data: A pragmatic synthesis. Hydrol. Earth Syst. Sci. 17, pp. 1331-1363.

Mauri A., Davis B.A.S., Collins P.M. and Kaplan J.O. (2015). The climate of Europe during the Holocene: a gridded pollen-based reconstruction and its multi-proxy evaluation. Quaternary Science Reviews, 112, pp. 109-127.

Mooney S.D. and Tinner W. (2011). The analysis of charcoal in peat and organic sediments. Mires and Peat, 7, pp. 1-18.

Nakagawa T., Tarasov P., Kotoba N., Gotanda K. and Yasuda Y. (2002). Quantitative pollenbased climate reconstruction in Japan: application to surface and late Quaternary spectra. Quaternary Science Reviews, 21, pp. 2099-2113.

Novenko E.Y., Zyuganova I.S., Olchev A.V. (2014) Application of the paleoanalog method for prediction of vegetation dynamics under climate changes. Doklady Biological Sciences 457(1), pp. 228-232.

Novenko E., Tsyganov A., Volkova E., Babeshko K., Lavrentiev N., Payne R. and MazeiYu. (2015). The Holocene palaeoenvironmental history of Central European Russia reconstructed from pollen, plant macrofossil and testate amoeba analyses of the Klukva peatland, Tula region. Quaternary Research, 83, pp. 459-468. 
Novenko E., Tsyganov A., Payne R., Mazei N., Volkova E., Chernyshov V., Kupriyanov D., and Mazei Yu. (2018). Vegetation dynamics and fire history at the southern boundary of the forest vegetation zone in European Russia during the middle and late Holocene. Holocene, 28(2), pp. 308-322.

Novenko E., Tsyganov A., Volkova E., Kupriyanov D., Mironenko I., Babeshko K., Utkina A., Popov V. and Mazei, Yu. (2016). Mid- and Late Holocene vegetation dynamics and fire history in the boreal forest of European Russia: A case study from Meshchera Lowlands. Palaeogeography, Palaeoclimatology, Palaeoecology, 459, pp. 570-584.

Novenko E.Yu., Eremeeva A.P. and Chepurnaya A.A. (2014). Reconstruction of Holocene vegetation, tree cover dynamics and human disturbances in central European Russia, using pollen and satellite data sets. Vegetation History and Archaeobotany, 23, pp. 109119.

Novenko E.Yu, Tsyganov A.N., Mazei N.G., Kupriyanov D.A., Rudenko O.V., Bobrovsky M.V., Erman N.M. and Nizovtsev V.A. (2018). Palaeoecological evidence for climatic and human impacts on vegetation in the temperate deciduous forest zone of European Russia during the last 4200 years: A case study from the Kaluzhskiye Zaseki Nature Reserve. Quaternary International (in press). doi:10.1016/j.quaint.2018.06.028.

Novenko E.Yu. and Olchev A.V. (2015). Early Holocene vegetation and climate dynamics in the central part of the East European Plain (Russia). Quaternary International, 388, pp. 1222.

Novenko E.Yu., Tsyganov A.N. and Olchev A.V. (2018). Palaeoecological data as a tool to predict possible future vegetation changes in the boreal forest zone of European Russia: a case study from the Central Forest Biosphere Reserve. IOP Conf. Series: Earth and Environmental Science, 107 (2017). 012104.

Olchev A. and Novenko E. (2011). Estimation of potential and actual evapotranspiration of boreal forest ecosystems in the European part of Russia during the Holocene. Environmental Research Letters, 6, 045213.

Olchev A., Novenko E., Desherevskaya O., Krasnorutskaya K., Kurbatova J. (2009). Effects of climatic changes on carbon dioxide and water vapor fluxes in boreal forest ecosystems of European part of Russia. Environmental Research Letters 4045007 (8pp).

Olchev A. and Novenko E. (2012) Evaporation of forest ecosystems in the Central part of European Russia during the Holocene. Mathematical Biology and Bioinformatics, 7(1), pp. 284-298.

Olchev A.V., Deshcherevskaya O.A., Kurbatova Y.A., Molchanov A.G., Novenko E.Y., Pridacha V.B., Sazonova T.A. (2013). CO2 and H2O exchange in the forest ecosystems of Southern Taiga under climate changes. Doklady Biological Sciences 450(1), pp. 173-176.

Payne R.J., Malysheva E., Tsyganov A., Pampura T., Novenko E., Volkova E., Babeshko K. and Mazei Y. (2016). A multi-proxy record of Holocene environmental change, peatland development and carbon accumulation from Staroselsky Moch peatland, Russia. The Holocene, 26(2), pp. 314-326.

Prentice I.C., Cramer W., Harrison S.P., Leemans R., Monserud R.A. and Solomon A.M. (1992). A global biome model based on plant physiology and dominance, soil properties and climate. Journal of Biogeography, 19, pp. 117-134. 
Priestley C.H.B., Taylor R.J. (1972). On the assessment of surface heat flux and evaporation using large-scale parameters. Monthly Weather Review, 100(2), pp. 81-92.

Rind D. and Lebedeff S. (1984) Potential Climatic Impacts of Increasing Atmospheric CO2 with Emphasis on Water Availability and Hydrology in the United States'. Report, Strategic Studies Staff, Office of Policy Anal., Office of Policy, Plann. and Eval., Washington D.C., 96 pp.

Sidorchuk A.Yu., Panin A.V. and Borisova O.K. (2012). River runoff decrease in North-Eurasian Plains during the Holocene Optimum. Water Resources, 39, pp. 69-81.

Solomina O.N., Bradley R.S., Hodgson D.A. et al. (2015). Holocene glacier fluctuations. Quaternary Science Reviews, 111, pp. 9-34.

Stančikaite M., Šinkŭnas P., Šeiriene V., Kisieliene D. (2008). Patterns and chronology of the Lateglacial environmental development at Pamerkiai and Kašučiai, Lithuania. Quaternary Science Reviews, 27, pp. 127-147.

Tarasov P.E., Bezrukova E.V. and Krivonogov S.K. (2009). Late Glacial and Holocene changes in vegetation cover and climate in southern Siberia derived from a $15 \mathrm{kyr}$ long pollen record from Lake Kotokel. Climate of the Past, 5, pp. 285-295.

Ter Braak C. (1995). Ordination. In: Jongman R., Ter Braak C., Van Tongeren O., eds. Data analysis in community and landscape ecology. Wageningen: Pudoc, pp 91-173.

Thomas E.R., Wolff E.W., Mulvaney, R. et al. (2007). The 8.2 ka event from Greenland ice cores. Quaternary Science Reviews, 26, pp. 70-81.

Tsyganov A.N., Babeshko K.V., Novenko E.Yu, Malysheva E.A., Payne R.J. and Mazei Y.A. (2017). Quantitative Reconstruction of Peatland Hydrological Regime with Fossil Testate Amoebae Communities. Russian Journal of Ecology, 48 (2), pp. 191-198.

Velichko A.A., Catto N., Drenova A.N. et al. (2002). Climate changes in East Europe and Siberia at the late glacial-Holocene transition. Quaternary International, 91, pp. 75-99.

Volkova E.M. (2011). Rare mires of the north-western Mid Russia Upland: vegetation and genesis. Botanical Journal, 96, pp. 55-70 (in Russian).

Wanner H., Beer J., Bütikofer J. et al. (2008). Mid- to Late Holocene climate change: an overview. Quaternary Science Reviews, 27, pp. 1791-1828.

Whitlock C. and Bartlein P.J. (2003). Holocene fire activity as a record of past environmental change. In: Gillespie A.R., Porter S.C., Atwater B.F., eds. The Quaternary period in the United States. Amsterdam: Elsevier, pp. 479-490.

Williams J.W. and Shuman B. (2008). Obtaining accurate and precise environmental reconstructions from the modern analog technique and North American surface pollen dataset. Quaternary Science Reviews, 27, pp. 669-687.

Willmott C.J. and Feddema J.J. (1992) A more rational climatic moisture index. Professional Geographer, 44, pp. 84-88.

UNEP (1992). World Atlas of Desertification. Edward Arnold, London. 
Zagwijn W.H. (1994). Reconstruction of climate change during the Holocene in western and central Europe based on pollen records of indicator species. Vegetation History and Archaeobotany, 3, pp. 65-88.

Received on November $7^{\text {th }}, 2018$

Accepted on May $17^{\text {th }}, 2019$ 